Anna Cegieła

DOI: 10.33896/PorJ.2020.4.5

(Uniwersytet Warszawski, e-mail: anna.cegiela@uw.edu.pl)

ORCID: 0000-0002- 6468-6318

\title{
MOWA NIENAWIŚCI
}

Słów nie należy liczyć, słowa trzeba ważyć.

[Roman Brandstaetter]

Obecność agresji językowej, manipulacji, retoryki pogardy, mowy nienawiści w przestrzeni publicznej - to pośredni i niezamierzony skutek wolności słowa gwarantowanej przez demokratyczny ustrój państwa. Zainteresowanie badaczy tymi negatywnymi ze społecznego punktu widzenia zjawiskami wynika po pierwsze ze świadomości, że są one elementami narracji dogmatycznej, a po drugie $z$ wiedzy o tym, do czego narracja dogmatyczna doprowadziła w przeszłości. Wymieniona wśród tych groźnych i niepożądanych w komunikacji zjawisk tzw. mowa nienawiści doczekała się już wielu opracowań, w których autorzy próbowali ustalić jej definicję, zakres oraz właściwości. Analizowanie mowy nienawiści jest trudne, ponieważ jest ona wpisana w kontekst polityczny, a sam termin ma kilka definicji - socjologiczna, psychologiczną i prawna.

Nazwa mowa nienawiści funkcjonuje także w polszczyźnie potocznej i wtedy ma funkcję zbliżoną do etykiety. Kiedy używaja jej publicyści, maja $\mathrm{w}$ gruncie rzeczy na myśli zachowania, w których przejawia się miażdżąca krytyka czyichś działań, agresja słowna albo zwykłe chamstwo. Postawienie komuś zarzutu stosowania mowy nienawiści jest zabiegiem majacym go skompromitować. Jest także oskarżeniem o czyn, za który grozi kara. Na takie nieprecyzyjne użycie i rozumienie terminu ma wpływ kilka czynników. Termin nie jest fortunny - zawiera nazwę antywartości, więc nie jest neutralny emocjonalnie. Przypisanie człowiekowi uczucia nienawiści automatycznie wywołuje do niego niechęć. Zapewne dlatego zarzut posłużenia się mową nienawiści w dyskusjach o polityce jest kierowany przeciwko konkurentom politycznym.

Określenie mowa nienawiści wprowadzili na grunt polski już w roku 2003) autorzy pracy Zamiast procesu. Raport o mowie nienawiści-Sergiusz Kowalski i Magdalena Tulli. Badacze przedstawili dwa sposoby rozumienia terminu - potoczny i oficjalny, uściślony przez organizacje zajmujące się przeciwdziałaniem ksenofobii, czyli komitety helsińskie, 
Amnesty International, Centrum Wiesenthala, European Commission against Racizm and Intolerance, Anti-Defamation League, Otwarta Rzeczpospolita itd.

W rozumieniu potocznym mowa nienawiści to każda lżąca, wyszydzająca i poniżająca ludzi wypowiedź. Organizacje zajmujące się zwalczaniem dyskryminacji ograniczaja rozumienie terminu do agresji werbalnej wobec mniejszości rasowych, religijnych, etnicznych i seksualnych.

S. Kowalski i M. Tulli precyzuja zakres zjawiska. Ich zdaniem mowa nienawiści jest adresowana do zbiorowości, a nie do jednostek i dzieje się tak nawet wtedy, gdy atakuje ona konkretna osobę. Traktuje ją bowiem nie jako jednostkę, lecz jako przedstawiciela grupy, której rzekome cechy i motywy zostaja mu przypisane [Kowalski, Tulli 2003, 21]. Zbiorowość będąca obiektem ataku to grupa naturalna, do której przynależności się nie wybiera, bo jest ona determinowana biologicznie (kolor skóry, przynależność etniczna) albo społecznie (język, religia). Autorzy podkreślają, że mowa nienawiści funkcjonuje w świecie wyobrażonym i sama wyznacza cel. Nie jest zatem ważne, czy atakowana osoba jest rzeczywiście gejem, Żydem, homoseksualista, masonem czy trockistą. Zauważaja ponadto, że kiedy obraża się człowieka jako przedstawiciela grupy etnicznej, religijnej lub innej, obraża się również tę grupę. Podobnie lub identycznie określają zakres mowy nienawiści inni badacze - np. Lech Nijałkowski i Michał Bilewicz.

Rada Europy definiuje mowę nienawiści jako

wszystkie formy ekspresji, które rozpowszechniaja, podżegaja, wspieraja lub usprawiedliwiają nienawiść rasowa, religijną, ksenofobię, antysemityzm lub inne formy nienawiści wynikające $z$ nietolerancji, łącznie $z$ nietolerancją wyrażoną za pomoca agresywnego nacjonalizmu i etnocentryzmu, dyskryminacją i wrogością wobec przedstawicieli mniejszości, imigrantów i osób obcego pochodzenia. ${ }^{1}$

Inne definicje określają mowę nienawiści jako wypowiedź atakująca, podburzająca do dyskryminacji lub nienawiści, a także, jak np. ta zamieszczona w Wikipedii, zaznaczaja, że negatywne emocjonalnie wypowiedzi są tworzone na podstawie uprzedzeń. Wszystkie znane mi definicje słownikowe i opisy mówią o tym, że obiektem ataku jest taka grupa, do której przynależności się nie wybiera. ${ }^{2}$ Adresatem natomiast może być zarówno ta właśnie grupa, jak i osoby do niej nienależące.

1 Definicji wprowadzanych przez Radę Europy jest kilka. Wszystkie sa nieprecyzyjne. Np. „wypowiedzi, które szerza, propagują i usprawiedliwiaja nienawiść rasowa, ksenofobię, antysemityzm oraz inne formy nietolerancji, podważające bezpieczeństwo demokratyczne, spoistość kulturowa i pluralizm”.

2 Por. np. Hate speech, speech or expression that denigrates a person or persons on the basis of (alleged) membership in a social group identified by attributes such as race, ethnicity, gender, sexual orientation, religion, age, physical or mental disability, and others [Encyclopedia Britannica]. 
Mowa nienawiści jest zjawiskiem pojawiajacym się głównie w mediach - najczęściej w Internecie, ale nie tylko - jest obecna również w przestrzeni miejskiej, na transparentach niesionych podczas różnych manifestacji, na ścianach domów, ogrodzeniach i na pomnikach.

Wypowiedzi należące do kategorii mowy nienawiści to komunikaty językowe i graficzne - rysunki, symbole, hasła, fotomontaże, przedstawienia, filmy itp. Repertuar nienawistnych komunikatów jest dość szeroki i obejmuje kilkadziesiąt różnych typów wypowiedzi. Te bezpośrednio dyskredytujące mówią o tym, kim ktoś (muzułmanin, Żyd, homoseksualista, liberał) jest, np. Grzegorz Ryś to żydowski deprawator polskiej młodzieży; jaki jest, np. każdy muzułmanin ma nierówno pod deklem; Ukrainiec, to potwór w ludzkiej skórze; co robi albo co zamierza zrobić: przyjeżdżaja, aby zmienić, zniszczyć, spalić i zgwałcić; talmudyczni imperialiści (...) chca wynaradawiać i dechrystianizować Polskę, okupić rozlewem niewinnej krwi; gejowski i talmudyczny kakol dażacy do destrukcji cywilizacji chrześcijańskiej; zamiary żydowskiego plemienia panowania nad światem; co powinno się $\mathrm{z}$ nim zrobić, np. A to $w$ pien tę swołocz trzeba wyciać albo zamknać $w$ jakimś ściśle chronionym rezerwacie...; Przerobić na karmę dla psów; Należy desakralizować ubiór biskupi Rysia poprzez zerwanie łańcucha $z$ krzyżem $i$ koloratki - chociaż jest watpliwe to, że zostały one ważnie poświęcone, ale liczy się pewna forma postępowania. Wziać pały, wypałować tych dwóch bandziorów, dominikanów wypędzić z Lublina! Banicja!!! (o biskupie i rabinie).

Inny rodzaj komunikatów - to prezentacja opinii i poglądów (w mniemaniu autorów zapewne nieszkodliwa, bo przecież subiektywna i nienarzucana innym): jedyna rzecz której żałuje to to że [Hitler] nie spalit wszystkich żydów; nie jest mi ich nawet [Żydów] żal... zasłużyli na to wszystko:-D. Specyficznym sposobem wyrażania opinii o Holocauście jest grafika zatytułowana $\dot{Z} y d z i$ prosto $z$ pieca. Nienawistny komunikat może mieć także postać rysunku przedstawiającego szubienicę $z$ powieszona gwiazda Dawida (zapewne wyrażającego życzenie albo groźbę). Wyrażającym nienawiść komunikatem jest także spalenie kukły przedstawiajacej Żyda, imigranta czy przedstawiciela jakiejś innej mniejszości. Taki akt ma charakter przemocy symbolicznej i można go rozumieć jako groźbę.

$Z$ perspektywy psychologii, socjologii oraz prawa zachowania dyskryminacyjne polegaja na nieuzasadnionej marginalizacji (a nawet wykluczeniu społecznym), objawiającej się przez traktowanie danej osoby mniej przychylnie niż innej w porównywalnej sytuacji ze względu na jakąś cechę, np. niepełnosprawność, płeć, wyznawana religię, światopogląd, narodowość itd. Mowa nienawiści (będąca przejawem dyskryminacji) to wypowiedzi, które budzą uczucia silnej niechęci, złości, braku akceptacji, wrogości do poszczególnych osób i grup społecznych, podtrzymują albo nasilaja takie negatywne nastawienie i w ten sposób podkreślają uprzywilejowanie albo wyższość określonego narodu, grupy etnicznej, 
rasy, religii. Taka definicja jest zrozumiała, ale zbyt ogólna, gdyż wystarczająco określa tylko funkcje mowy nienawiści. Nie umożliwia natomiast jednoznacznego rozpoznania nienawistnych komunikatów, bo nie podaje ich cech językowych czy w ogóle semantycznych.

Warto uwypuklić istotną właściwość tej specyficznej dyskryminacji, a mianowicie to, że osobom dyskryminowanym formalnie nie odbiera się żadnych praw. Swoistość mowy nienawiści polega na tym, że wskazuje ona i określa człowieka w taki sposób, żeby dla innych stało się jasne, że nie zasługuje on na normalne traktowanie, a więc wolno go traktować gorzej. Komunikat o przedstawicielach mniejszości przekazuje treść: 'on nie jest w pełni człowiekiem, ma cechy groźne dla normalnych ludzi, gardzę nim i wskazuję mu jego miejsce'. Inaczej mówiąc, wypowiadający komunikat nienawiści dopuszcza obecność pewnych ludzi w społeczeństwie, ale na swoich zasadach, niejako warunkowo, na marginesie. Nie pozbawia ich praw, ale też nie pozwala $z$ nich korzystać w pełni, czyniąc jednocześnie winnymi takiego stanu rzeczy. Skrajnie radykalne komunikaty nie traktują innych (np. ciemnoskórych, homoseksualistów) jak ludzi i zapowiadaja odebranie im praw: Cała Polska tylko biała; Europa bedzie biała albo bezludna; Cała Polska śpiewa $z$ nami: wy...ć z pedałami; Zrobimy $z$ wami, co Hitler $z$ Żydami; A na drzewach zamiast liści będa wisieć islamiści!

Mowa nienawiści spełnia zasadnicze kryterium dogmatycznej narracji o świecie - wyraża nietolerancję dla inności - religii, poglądów, narodowości, rasy itd., dzieli świat na nasz i świat innych, gorszych. Inny jest obiektem obcym, niebezpiecznym, wrogim i stanowi zagrożenie porządku społecznego, który to porządek ma prawo ustanawiać nadawca nienawistnego komunikatu.

Charakterystyczne dla mowy nienawiści jest również racjonalizowanie wypowiedzi piętnujących przedstawicieli mniejszości oraz postaw wrogości, czyli uzasadnianie swojego prawa do stosowania mowy nienawiści, co daje się zaobserwować szczególnie w tekstach o charakterze antysemickim (ale nie tylko). Tym samym jednocześnie ze wskazaniem osób niezasługujących na normalne traktowanie demonstruje się przyznawanie specjalnego prawa innym osobom - tym, które piętnuja przedstawicieli mniejszości i ubliżaja im, grożą oraz nawołują do przemocy. Tego rodzaju wypowiedzi maja zwykle prosty schemat: zasłużyli sobie na niechęć, złe traktowanie, śmierć, bo kiedyś (tu zwykle chodzi o przeszłość historyczną) członkowie ich grupy zrobili nam (a dokładniej naszym przodkom) coś złego. Przykład takiego komunikatu znalazł się na Facebooku: To chazarskie żydostwo mordowało Polaków w Katyniu. Obok widniała grafika przedstawiajaca karykaturę Żyda oraz Gwiazdę Dawida, w która były wpisane sierp i młot, a powyżej widniał napis Communism is a Jewish Conspiracy.

$Z$ perspektywy etyki komunikacji dla opisu nieetycznych wypowiedzi, a więc i mowy nienawiści, najbardziej przydatne sa narzędzia krytycz- 
nej analizy dyskursu oraz teoria aktów mowy. Analizowane komunikaty różnią się między soba rodzajem zastosowanego zabiegu komunikacyjnego oraz stopniem szkodliwości. Można więc opisać jakieś zachowanie, określając je jako redukujące człowieka do jednej cechy, etykietujące go, dehumanizujace i depersonifikujące, albo uznać akt komunikacji np. za groźbę, ostrzeżenie czy nakaz podporządkowania się regule narzuconej przez nadawcę. Przydatne jest tu również rozróżnienie wprowadzone przez Tymothy'ego G. Asha i Susan Benesch (na portalu „Free Speech Debate") na hate speech (mowa nienawiści) oraz dangerous speech (mowa niebezpieczna). T.G. Ash i S. Benesch posługuja się jednak nieco inna niż tu przywołane definicją mowy nienawiści. Odróżniają oni ekspresję emocji, wypowiedzi poniżające i szydzące (to właśnie określają mianem hate speech) od nawolywania do przemocy (dangerous speech). Pierwszej przyznaja prawo bytu w ramach szeroko pojętej wolności słowa w demokracji liberalnej. Przyznaja, że hate speech powinna być potępiana moralnie. Natomiast karać należy za wypowiedzi nawołujace do przemocy i określane jako mowa niebezpieczna. Tymothy G. Ash rozgranicza jednak w obrębie mowy nienawiści mówienie lekceważące, szydercze i pogardliwe o przekonaniach, wierze, tabu, działaniach itd. i dopuszcza je w dyskursie publicznym, od szydzenia i poniżania człowieka, co uważa już za niedopuszczalne. Takie rozgraniczenie wydaje się ogólnie słuszne, ale nie jest wystarczajace. T.G. Ash twierdzi bowiem, że można mówić $z$ pogardą czy $z$ kpiną o każdej religii oraz związanej $z$ nią sfera sacrum. Nie można jedynie wyrażać się $z$ pogarda o wyznawcach religii. Wydaje się, że przyjęcie takiej zasady nie uwzględnia wagi przekonań religijnych oraz innych ważnych tabu. Obrażając to, co ulokowane jest w sferze sacrum, uderza się pośrednio w człowieka, dla którego ta sfera jest istotna np. ze względów moralnych.

Analizowane komunikaty różnią się między sobą rodzajem zastosowanego zabiegu komunikacyjnego oraz stopniem szkodliwości. Można więc opisać jakieś zachowanie, określając je jako redukujące człowieka do jednej cechy, etykietujące go, dehumanizujące i depersonifikujące albo uznać akt komunikacji np. za groźbę, ostrzeżenie czy nakaz podporządkowania się regule narzuconej przez nadawcę.

Krzywda uczyniona ludziom zależy od kilku czynników: od tego, kto jest nadawcą wypowiedzi i jakie ma intencje (jeśli da się rozpoznać), od okoliczności wypowiedzi i audytorium, od zawartości lokucyjnej tekstu. Można uznać, że najważniejszy w ocenie komunikatu jest skutek perlokucyjny, ale ocena całego zabiegu komunikacyjnego musi uwzględniać intencję nadawcy (która nie musi być zła) oraz konkretna sytuację wypowiedzi.

Nadawca mający autorytet, pozycję i np. możliwość wypowiadania się w mediach może wpłynąc na postawy wielu osób, a tym samym uczynić większą krzywdę niż osoba, która rzuci złośliwa i wulgarna uwagę $\mathrm{w}$ tramwaju. Tekst wartościujący negatywnie jakąś grupę ludzi np. ze 
względów etnicznych, ale wypowiedziany w wąskim gronie znajomych, może być nieszkodliwy albo mało szkodliwy (znajomi nie musza podzielać poglądów nadawcy ani ich przyjmować, moga ich także nie aprobować). Taki sam tekst adresowany do dużego grona ludzi np. na manifestacji ma już większy potencjał szkodzenia. Nawoływanie do przemocy może się skończyć atakiem fizycznym. Dla etyki komunikacji jest istotne, czy krzywdząca wypowiedź była intencjonalna i jaką szkodę uczyniła, czy była narzędziem osiagania własnych celów nadawcy kosztem odbiorcy.

$Z$ tego punktu widzenia mowa nienawiści jest w przeważającej liczbie wypadków rodzajem przemocy komunikacyjnej. Wypowiadający słowa albo rysujacy obraz działa celowo. Przyznaje sobie prawo wprowadzania elementów ładu społecznego, których inni nie akceptuja, a więc działa niejako z pozycji dominującej. Jego celem jest skuteczne napiętnowanie, poniżenie, zastraszenie kogoś, wmówienie słuchaczom, że ten ktoś jest gorszy od innych itp., czyli wyznaczenie mu miejsca i zbudowanie własnej pozycji na demonstrowaniu siły wobec osób słabszych. Mowa nienawiści ma charakter przemocy psychicznej - uniemożliwia utrzymanie równowagi psychicznej, poczucia tożsamości i godności, odbiera poczucie bezpieczeństwa, motywację do życia, czasem także możliwość działania.

Zachowania komunikacyjne o charakterze przemocy moga mieć różny charakter - moga przyjać postać kłamstwa, fałszywej atrybucji, groźby, obelg, inwektyw, bezpośredniego nawoływania do przemocy. O tym, czy należą one do kategorii mowy nienawiści, decyduja dwie ich właściwości, a mianowicie to, czy sa komunikatami dyskryminujacymi oraz to, przeciw komu sa skierowane, kto jest ich ofiara. Budzi to nawet pewien sprzeciw użytkowników języka, którzy dostrzegają nieetyczność wielu komunikatów, ale nie rozumieja, dlaczego akurat wypowiedzi dyskryminujące mniejszości sa karalne. Nie biora pod uwagę tego, że są one seryjne i marginalizuja lub wykluczaja całe grupy ludzi na podstawie przypisywanych im cech ani tego, że mniejszość jest grupa słabsza.

$\mathrm{W}$ odniesieniu do mowy nienawiści samo ujawnienie mechanizmu językowego jest oczywiście pożyteczne w analizie, ale nie wystarcza do rozpoznania zjawiska, bo zabiegi redukujące czy naruszające suwerenność człowieka są stosowane wobec różnych osób, na przykład w konkurencji politycznej. Czasem trudno orzec, czy jakiś zabieg jest celem samym w sobie, czy też ma służyć osiagnięciu innych celów (poniżanie może prowadzić do marginalizacji, ale może też zastraszać).

Do badań nad dyskryminacja, dla organizacji antydyskryminacyjnych i prawników opisowa definicja mowy nienawiści wyliczająca jej właściwości nie jest wystarczająca. Potrzebne są takie kryteria, które pozwoliłyby na jednoznaczne uznanie jakiejś wypowiedzi za mowę nienawiści oraz odróżnienie jej od innych nieetycznych zachowań komunikacyjnych, w tym językowych, i to na tyle wyraźnie, by nie było watpliwości, że mamy do czynienia $z$ dyskryminacją szczególnego rodzaju - ze względu na przynależność do konkretnej grupy. 
Kryteria dotychczas przywoływane maja najczęściej charakter psychologiczny albo prawny. Trudniej jest wskazać językoznawcze narzędzia rozpoznawania i opisu, a to one byłyby tu najbardziej potrzebne.

Dobra propozycje metodologiczna rozwiazania tego problemu przedstawiła kilka lat temu Jadwiga Linde-Usiekniewicz [Linde-Usiekniewicz 2015]. Autorka sądzi, że narzędzia językoznawcze pozwalaja na znalezienie przejawów mowy nienawiści, a także retoryki nienawiści przede wszystkim na poziomie czynności lokucyjnych, ale zawodzą w odniesieniu do aktów mowy niejawnych i pośrednich. Dlatego zaproponowała sięgnięcie do teorii relewancji i na jej gruncie sformułowała definicję mowy nienawiści. Oparła ją na ważnych i przydatnych założeniach zaczerpniętych $z$ pracy D. Sperbera i D. Wilson.

J. Linde-Usiekniewicz pisze zatem, że wypowiedzi językowe i komunikaty innego rodzaju można traktować jednakowo, gdyż ich odkodowanie uruchamia takie same procesy inferencyjne, a interpretowanie podlega zasadzie relewancji. Potencjalna zawartość komunikatu jest tym bardziej relewantna, im mniejszy jest wysiłek poznawczy potrzebny do jego przetworzenia. Wysiłek poznawczy i efekty poznawcze zależą od otoczenia kognitywnego odbiorcy, czyli dostępnych przesłanek, a wśród nich własnych przekonań oraz przekonań o przekonaniach cudzych. Zasadnicza rolę w interpretacji wypowiedzi badaczka przyznaje odczytywaniu eksplikatur, czyli tego, co jest wyrażane eksplicytnie i jest odczytane po ustaleniu odniesień i rozwiąaniu wieloznaczności (wynikającej z tekstu, a wyjaśnionej dzięki kontekstowi).

Po przedstawieniu tych założeń J. Linde-Usiekniewicz proponuje własną definicję mowy nienawiści.

Jest to taka wypowiedź, do której optymalnego przetworzenia niezbędne sa przesłanki (czyli przekonania lub reprezentacje przekonań) dotyczące tego, że jakaś grupa - w tej wypowiedzi przywołana i zdefiniowana przez cechy uznawane za stałe - jest gorsza pod jakimś względem, a przez to zasługuje na gorsze traktowanie i że osoba lub osoby, do których ta wypowiedź się odnosi, należą do tej grupy [Linde-Usiekniewicz 2015].

Definicja ta na gruncie teorii relewancji nie stanowi jakiegoś nietypowego modelu rozumienia wypowiedzi. Wprowadza jednak warunek optymalizacji przetwarzania komunikatu - jest nim wyrażone przekonanie nadawcy komunikatu o tym, że jakaś grupa ludzi jest gorsza od innych, a osoba, o której jest mowa, należy do tej właśnie grupy. W tym rozumieniu mowa nienawiści sa wypowiedzi atakujące przedstawicieli grup etnicznych, mniejszości rasowych, religijnych i seksualnych ze względu na cechy (postrzegane jako niezależne od woli jednostki). Nie należą natomiast do tej kategorii komunikaty poniżające czy zastraszające ludzi ze względu na poglądy polityczne i inne cechy świadomie nabyte.

Przesłankami zapewniajacymi właściwe rozumienie komunikatu moga być zarówno typy zabiegów językowych - hiperbolizacje, uogólnienia, stygmatyzacja, dehumanizacja, jak i konkretne leksemy. Większość 
zabiegów należy do przesłanek mieszczacych się w zakresie eksplikatury, podobnie jak określenia poniżające i uwłaczające ludzkiej godności. Do implikatury z kolei należy np. wyróżnione przez L. Nijałkowskiego podważanie rytuałów poważania. Wiedza o tym, że stygmatyzuje się grupy uznawane za gorsze oraz o tym, że dehumanizacja i hiperbolizacja sa środkami, które pozwalaja to dostrzec, sa przesłankami, które umożliwiają ustalenie skutku perlokucyjnego mowy nienawiści. Jest nim odebranie godności ofiarom nienawistnego komunikatu.

Propozycja J. Linde-Usiekniewicz dobrze porządkuje rozumienie mowy nienawiści na gruncie jednej teorii, pozwala na spójny metodologicznie sposób opisu zjawiska, co jest jej ogromna zaletą. Umożliwia uznanie za mowę nienawiści takich komunikatów, które pozornie nią nie są i nie dadzą się zakwalifikować przez sąd do kategorii gróźb karalnych na przykład ze względu na obecność odbierającego wypowiedzi właściwość rozkazu wykładnika gramatycznego czasu przyszłego. Autorka artykułu posłużyła się następującym przykładem: Wyzwolimy Polskę od euro-zdrajców, Żydów, masonów i rządowej mafii. Hasło to jest zapowiedzia, a nie wezwaniem. Nie zostało zatem uznane za nawoływanie do jakichś czynów. Sąd uznał ponadto, że nie spełnia ono kryteriów mowy nienawiści. Zgodnie $z$ definicją opartą na teorii relewancji (także zgodnie $z$ analiza, która przeprowadza się na gruncie etyki komunikacji) komunikat ten ma wyraźnie charakter dyskryminujący. Pozwalają to ustalić następujące, łatwo dostępne przesłanki dotyczace otoczenia kognitywnego odbiorcy komunikatu. Pierwsza to wiedza o tym, że wyzwala się (kraj, Polskę, jakaśs grupę) od czegoś złego, np. innej, wrogiej, czyniącej szkody grupy. Druga przesłanka, również łatwo dostępna, to informacja, że wrogami Polski sa eurozdrajcy, Żydzi, masoni i rządowa mafia. Hasło podaje jednoznaczne nazwy tych wrogów. Trzecia przesłanka, również łatwo dostępna, to wniosek, że należy pozbyć się tych grup. Hasło jest zatem mową nienawiści, bo dyskryminuje konkretne grupy ludzi - wymienia je wprost i pośrednio określa mianem wrogów. Doprecyzowując: przynależność do grupy eurozdrajców (tym jednoznacznie negatywnie wartościującym leksemem określono kilka osób znanych $z$ imienia i nazwiska), Żydów i masonów oznacza bycie gorszym (wrogiem, od którego niosacy transparent chcą wyzwolić Polskę). A zatem hasło jednoznacznie dyskredytuje i dyskryminuje ludzi ze względu na przynależność do tych grup i przynajmniej w odniesieniu do Żydów (grupy, do której przynależności się nie wybiera) jest mową nienawiści.

Przedstawiony przykład to wypadek jednoznaczny - hasło jest intencjonalne, treść zrozumiała, skutek w postaci wywołania co najmniej silnej niechęci oczywisty. Podobnie da się ocenić kilkanaście innych wypowiedzi, które budzą wątpliwości sądu albo prokuratury: tęczowa zaraza, żydowski nowotwór i motłoch, żydowska okupacja, pie...ny pedal $w$ rurkach... wrecz wskazane jest bicie takiego gowna do krwi (pisownia oryginalna). W świetle teorii relewancji treścia tych wypowiedzi jest to, co pozwalają zrozumieć łatwo dostępne przesłanki. 
Dla etyki komunikacji opis mieszczacy się w ramach teorii relewancji ma pewne niedostatki. Ustalenie, że jakiś akt komunikacji jest mowa nienawiści, a raczej że formalnie przynależy do tej kategorii wypowiedzi, nie w każdym wypadku wystarcza do sformułowania właściwej oceny etycznej, a także prawnej. W zakresie tzw. otoczenia kognitywnego nie mieszczą się bowiem wszystkie okoliczności wypowiedzi i motywacja, a ściślej inna motywacja niż ta, która można autorowi przypisać na podstawie treści komunikatu (po prostu psychologiczna przyczyna reakcji słownej).

Posłużmy się przykładem. Pod postem ze zdjęciem polskiego kierowcy, który zginą w zamachu terrorystycznym w Berlinie 19 grudnia 2016 r., znalazł się następujacy wpis:

Nie jestem rasistka ale krew mi już buzuje jak słyszę co wyprawiają. Zginęło 12 osób zabić 12-tu muzułmanów niech wiedza ze poniosa takie same żniwo swoich czynów!!!!!! [pisownia oryginalna].

Wpis jednoznacznie nawołuje do zemsty i stereotypizuje muzułmanów jako terrorystów. Jest oczywistym przykładem mowy nienawiści. Wskazuje na to sam typ zabiegu. Prokuratura Rejonowa dla Warszawy Ochoty odmówiła jednak wszczęcia dochodzenia. Uznała, że komentarz stanowił impulsywna reakcję na silne, negatywne emocje wywołane skutkami zamachu dokonanego przez muzułmańskiego ekstremistę [XI.518.18.2017].

Ocena etyczna tego wpisu także uwzględniłaby wpływ emocji na reakcję internautki. Nie da się jednak wykryć tych emocji jedynie na podstawie zawartości słownej wpisu. Aby w miarę obiektywnie ocenić zachowanie internautki, trzeba wziąc pod uwagę informacje podawane na temat tego zamachu w mediach, ich treść i częstotliwość napływania nowych wiadomości o jego przebiegu, a także o tym, kim był zabity Polak i jak się zachowywał. Wymienione tu okoliczności miały bezpośredni i silny wpływ na emocje wielu odbiorców. Wyrażali oni zarówno podziw dla Polaka próbującego się bronić przed zamachowcem, współczucie dla jego rodziny, jak i oburzenie, nienawiść do terrorysty i dezaprobatę w stosunku do powolnie prowadzonego śledztwa. Reakcja internautki była zatem mało rozsądna, emocjonalna, ale raczej wynikająca $z$ treści przekazów o faktach, a nie utrwalonych przekonań.

Półgodzinny przegląd postów będących reakcjami na słowa polityków, wypowiedzi dziennikarzy i aktorów, a nawet na artykuły, pozwala zaobserwować dość schematyczne i groźnie wyglądające propozycje tego, co należy zrobić $z$ członkami PiS-u, biskupami, przedstawicielami Wiosny, PO itd. Internauci proponuja wywiezienie na bezludna wyspę, powieszenie, zabetonowanie żywcem, zamknięcie w więzieniach, zsyłkę do Rosji i na Kubę, obcięcie różnych części ciała, powieszenie i rozjechanie. Nie powinno się wszystkich takich tekstów traktować dosłownie, sa bowiem ekspresja negatywnych emocji, a w wielu wypadkach próba sprowoko- 
wania dyskusji z przeciwnikami. Na tym tle wpis internautki był stereotypowy i emocjonalny. Trudno uznać, że mógłby on przekonać kogoś do zabicia 12 muzułmanów.

Incydent pokazuje jednak ważny problem. Ocena wypowiedzi nie może ograniczać się do analizy samej treści. Istnieje bowiem duże prawdopodobieństwo, że treść nie wyraża przekonań, lecz emocje (np. oburzenie i strach) albo stanowi reakcję obronną również wywołaną przez emocje. Tak należałoby ocenić wpis Mariusza Pudzianowskiego, który zamieścił na Facebooku zdjęcie mężczyzny z kijem bejsbolowym oraz tekst:

$Z$ tym będę czekał na naczepie do UK przed wjazdem na prom $z$ Calais (...). Na naczepie będzie przyspieszona nauka asymilacji.

Pudzianowski dodał jeszcze, że ma prawo się bronić. Miał to być komentarz do informacji o napaściach grup migrantów na ciężarówki w porcie Calais. Można dyskutować o tym, czy wpis jest ostrzeżeniem czy groźba, ale trudno uznać go za mowę nienawiści, zwłaszcza w kontekście medialnych doniesień o zachowaniu się imigrantów. Ważnym kryterium oceny wypowiedzi pod kątem jej przynależności do kategorii nienawistnej mowy powinna być racjonalność działania nadawcy. Działanie pod wpływem emocji może być oczywiście szkodliwe, ale ocena wypowiedzi nadawcy musi uwzględniać także cel wypowiedzi, a nie tylko jej możliwy skutek.

Nie sądzę również, by zawsze w wypadku nienawistnych wpisów potrzebne było śledztwo. Wystarczyłby komunikat jakiejś organizacji antydyskryminacyjnej informujący o tym, że zauważyła ona wpis i dostrzega w nim cechy mowy nienawiści. Sankcje prawne sa raczej środkiem ostatecznym i bardziej przydatnym w jednoznacznych sytuacjach opisanych wcześniej. Aby ograniczyć występowanie mowy nienawiści, potrzebna jest przede wszystkim edukacja.

\section{Bibliografia}

M. Bilewicz, D. Bulska, K. Hansen, W. Soral, A. Świderska, M. Winiewski, 2016, Mowa nienawiści. Raport z badania przemocy werbalnej wobec grup mniejszościowych, Warszawa.

J. Butler, 2010, Walczace słowa. Mowa nienawiści i polityka performatywu, tłum. A. Ostolski, Warszawa.

A. Cegieła, 2014, Czym jest mowa nienawiści, „Poradnik Językowy” z. 1, s. 7-17.

A. Cegieła, 2014, Słowa i ludzie. Wprowadzenie do etyki słowa, Warszawa.

S. Kowalski, M. Tulli, 2003, Zamiast procesu. Raport o mowie nienawiści, Warszawa.

J. Linde-Usiekniewicz, 2015, Teoria relewancji jako narzędzie opisu mowy nienawiści, „Studia Pragmalingwistyczne” r. VII, s. 53-67.

L. Nijałkowski, 2008, Mowa nienawiści w świetle teorii dyskursu [w:] A. Horolets (red.), Analiza dyskursu w socjologii i dla socjologii, Torun, s. 113-133. 


\section{Hate speech}

\section{Summary}

Hate speech is an object of interest among representatives of various disciplines. Sociology describes it as discrimination of the social groups in which one is a member regardless of their will. Hate speech is defined similarly from the angle of political correctness. Communication ethics treats hate speech as a variety of communication violence and an element of the exclusion strategy. Due to the legal consequences of using hate speech, linguistic criteria for recognising it are necessary. They are proposed by Jadwiga Linde-Usiekniewicz, who draws on the relevance theory. A thorough assessment of the utterance or statement categorised as hate speech requires, however, an analysis of a broader situational context.

Keywords: hate speech - communication violence - relevance theory.

Trans. Monika Czarnecka 